Supporting Information for

\title{
Unprecedented Intramolecular Electron Transfer from Excited Perylenediimide Radical Anion
}

Chao Lu, Mamoru Fujitsuka, * Akira Sugimoto, and Tetsuro Majima*

The Institute of Scientific and Industrial Research (SANKEN), Osaka University, Mihogaoka

8-1, Ibaraki, Osaka 567-0047, Japan

Corresponding authors:

*M. Fujitsuka. E-mail: fuji@sanken.osaka-u.ac.jp

*T. Majima. E-mail: majima@sanken.osaka-u.ac.jp

\section{Synthesis}

\section{1-Hexylheptylamine (1)}

$2.54 \mathrm{~g}$ (12.80 mmol) 7-Tridecanone, $9.75 \mathrm{~g}$ (126 mmol) $\mathrm{NH}_{4} \mathrm{OAc}$, and $0.57 \mathrm{~g}$ (9.08 mmol) $\mathrm{NaBH}_{3} \mathrm{CN}$ were dissolved in $30 \mathrm{~mL} \mathrm{MeOH}$ and stirred at room temperature for $2 \mathrm{~d}$. The mixture was quenched by adding $2 \mathrm{~mL}$ of $2 \mathrm{M} \mathrm{HCl}$ and then concentrated with a rotary evaporator. The 
resulting white solid was dispersed in $200 \mathrm{~mL} \mathrm{H}_{2} \mathrm{O}$, adjusted to $\mathrm{pH}=10$ with $\mathrm{KOH}$, and extracted by $300 \mathrm{~mL}$ and then $150 \mathrm{~mL}$ of $\mathrm{CHCl}_{3}$. The pale yellow oil $1(2.34 \mathrm{~g}, 11.73 \mathrm{mmol}, 92 \%)$ was obtained by concentrating the $\mathrm{CHCl}_{3}$ fractions.

${ }^{1} \mathrm{H} \mathrm{NMR}\left(\mathrm{CDCl}_{3}, 400 \mathrm{MHz}\right): \delta 0.87(\mathrm{t}, J=6.4 \mathrm{~Hz}, 6 \mathrm{H}), 1.28(\mathrm{~m}, 20 \mathrm{H}), 1.96(\mathrm{~m}, 1 \mathrm{H}), 2.66(\mathrm{br}$, $2 \mathrm{H})$.

\section{$N, N^{\prime}$-Bis(1-hexylheptyl)perylene-3,4,9,10-tetracarboxylbisimide (2)}

$$
2.34 \mathrm{~g} \quad(11.73 \mathrm{mmol}) \quad \mathbf{1} \text { and } 6.00 \mathrm{~g} \quad(15.30 \mathrm{mmol}) \text { perylene-3,4,9,10- }
$$
tetracarboxylicdianhydride in $15 \mathrm{~g}$ imidazole were stirred $2 \mathrm{~h}$ at $160{ }^{\circ} \mathrm{C}$. The reaction mixture was cooled to room temperature, dispersed in $100 \mathrm{~mL}$ methanol. The dark red precipitate was filled and dried over $\mathrm{Na}_{2} \mathrm{SO}_{4}$. Further purification was carried by column chromatography (silica gel; chloroform) to obtain the red solid 2 (8.57 g, $11.36 \mathrm{mmol}, 97 \%)$.

${ }^{1} \mathrm{H} \mathrm{NMR}\left(\mathrm{CDCl}_{3}, 400 \mathrm{MHz}\right): \delta 0.81(\mathrm{t}, J=6.9 \mathrm{~Hz}, 12 \mathrm{H}), 1.21(\mathrm{~m}, 32 \mathrm{H}), 1.82(\mathrm{~m}, 4 \mathrm{H}), 2.20(\mathrm{~m}$, 4H), $5.15(\mathrm{~m}, 2 \mathrm{H}), 8.64(\mathrm{~m}, 8 \mathrm{H})$.

\section{$N$-(1-Hexylheptyl)perylene-3,4,9,10-tetracarboxyl-3,4-anhydride-9,10-imide (3)}

$8.57 \mathrm{~g}(11.36 \mathrm{mmol}) 2$ was suspended in $250 \mathrm{~mL} t$-BuOH and treated with $0.74 \mathrm{~g}(13.13 \mathrm{mmol})$ solid $\mathrm{KOH}$. The reaction mixture was heated with stirring to reflux for $2 \mathrm{~h}$. The mixture was cooled to room temperature, treated with $180 \mathrm{~mL}$ acetic acid and then $60 \mathrm{~mL}$ of $2 \mathrm{M} \mathrm{HCl}$ and stirred overnight. The precipitate was filtered, washed with distilled water, and dried in a vacuum oven at $90{ }^{\circ} \mathrm{C}$. Further purification was carried by column chromatography (silica gel; chloroform) to obtain the dark red solid 3 (2.67 g, $4.65 \mathrm{mmol}, 41 \%)$. 
${ }^{1} \mathrm{H}$ NMR $\left(\mathrm{CDCl}_{3}, 400 \mathrm{MHz}\right): \delta 0.81(\mathrm{t}, J=6.9 \mathrm{~Hz}, 6 \mathrm{H}), 1.23(\mathrm{~m}, 12 \mathrm{H}), 1.84(\mathrm{~m}, 4 \mathrm{H}), 2.20(\mathrm{~m}$, 4H), $5.15(\mathrm{~m}, 1 \mathrm{H}), 8.57(\mathrm{~m}, 8 \mathrm{H})$.

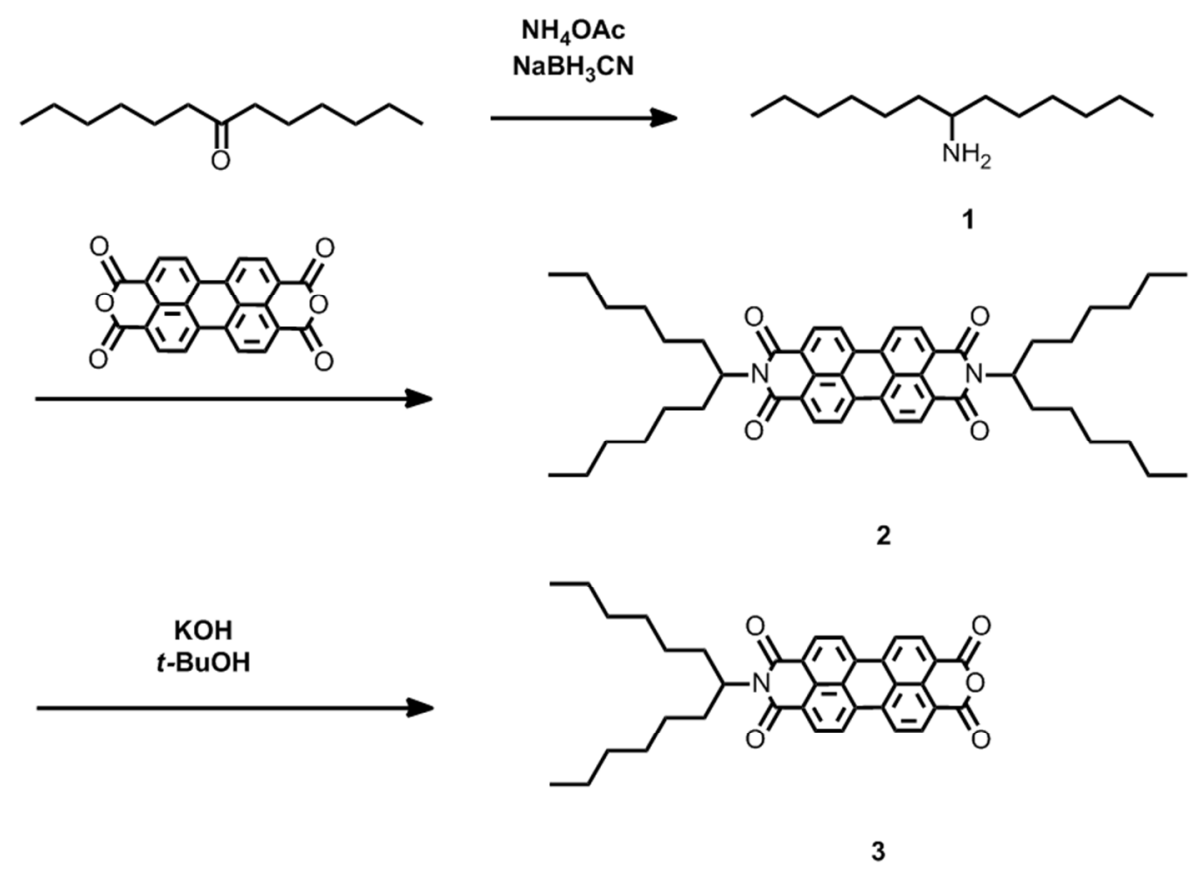

Scheme S1

\section{PDI}

$3(0.10 \mathrm{~g}, 0.17 \mathrm{mmol})$ and aniline $(48 \mathrm{mg}, 0.51 \mathrm{mmol})$ were dissolved in $50 \mathrm{~mL}$ of DMF. The reaction mixture was heated with stirring to reflux for $24 \mathrm{~h}$ under argon atmosphere. Afterwards the reaction mixture was evaporated in vacuo and further purified by column chromatography (silica gel; chloroform) to obtain the dark red solid PDI (44 mg, $0.068 \mathrm{mmol}, 40 \%$ ).

${ }^{1} \mathrm{H} \mathrm{NMR}\left(\mathrm{CDCl}_{3}, 400 \mathrm{MHz}\right): \delta 0.82(\mathrm{t}, J=7.2 \mathrm{~Hz}, 6 \mathrm{H}), 1.21(\mathrm{~m}, 12 \mathrm{H}), 1.84(\mathrm{~m}, 4 \mathrm{H}), 2.22(\mathrm{~m}$, 4H), $5.17(\mathrm{~m}, 1 \mathrm{H}), 7.36(\mathrm{~d}, J=8.3 \mathrm{~Hz}, 2 \mathrm{H}), 7.51(\mathrm{t}, J=7.6 \mathrm{~Hz}, 1 \mathrm{H}), 7.58(\mathrm{t}, J=7.6 \mathrm{~Hz}, 2 \mathrm{H})$, $8.68(\mathrm{~m}, 8 \mathrm{H})$. 


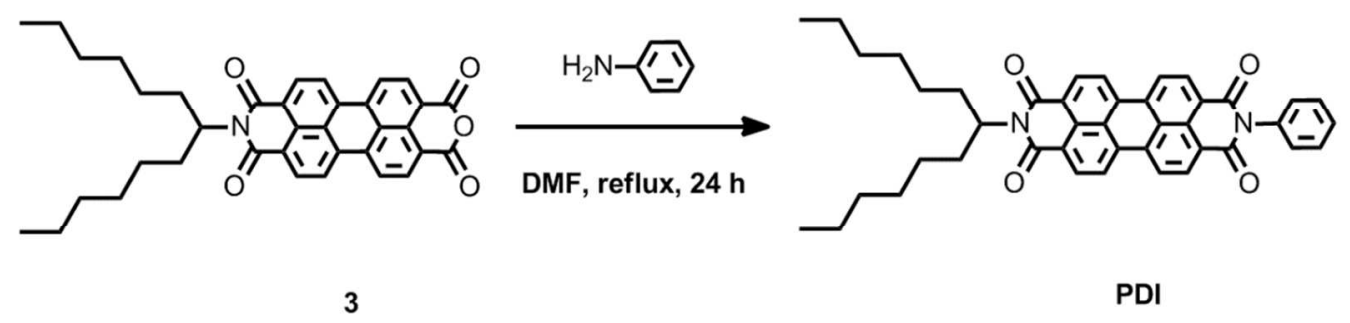

Scheme S2

\section{$N$-(3-Aminophenyl)phthalimide (4)}

Phthalic anhydride (3.01 g, $20.32 \mathrm{mmol})$ and $m$-phenylenediamine $(2.19 \mathrm{~g}, 20.25 \mathrm{mmol})$ were dissolved in $30 \mathrm{~mL}$ of DMF. The reaction mixture was heated with stirring at $110{ }^{\circ} \mathrm{C}$ for $24 \mathrm{~h}$ under argon atmosphere. Afterwards the reaction mixture was evaporated in vacuo and further purified by column chromatography (silica gel; dichloromethane) to obtain the pale yellow solid $4(1.76 \mathrm{~g}, 7.39 \mathrm{mmol}, 36 \%)$.

${ }^{1} \mathrm{H} \mathrm{NMR}\left(\mathrm{CDCl}_{3}, 400 \mathrm{MHz}\right): \delta 3.79(\mathrm{br}, 2 \mathrm{H}), 6.70(\mathrm{~m}, 1 \mathrm{H}), 6.73(\mathrm{~m}, 1 \mathrm{H}), 6.80(\mathrm{~d}, J=7.8 \mathrm{~Hz}$, 1H), $7.25(\mathrm{t}, J=3.9 \mathrm{~Hz}, 1 \mathrm{H}), 7.77(\mathrm{~m}, 2 \mathrm{H}), 7.94(\mathrm{~m}, 2 \mathrm{H})$.

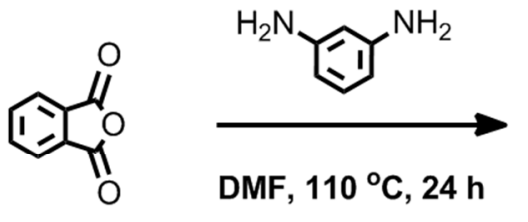

DMF, $110^{\circ} \mathrm{C}, 24 \mathrm{~h}$<smiles>Nc1cccc(N2C(=O)c3ccccc3C2=O)c1</smiles>

4

\section{Scheme S3}

\section{PDI-Ph}


$4(0.20 \mathrm{~g}, 0.84 \mathrm{mmol})$ and $3(0.32 \mathrm{~g}, 0.56 \mathrm{mmol})$ were dissolved in $10 \mathrm{~mL}$ of DMF. The reaction mixture was heated with stirring to reflux for $24 \mathrm{~h}$ under argon atmosphere. Afterwards the reaction mixture was evaporated in vacuo and purified by column chromatography (silica gel; chloroform). Further purification was carried by column chromatography (silica gel; chloroform/ethyl acetate (gradient)) to obtain the dark red solid PDI-Ph (48 mg, $0.06 \mathrm{mmol}$, $11 \%)$.

${ }^{1} \mathrm{H}$ NMR (CDCl $\left.3,400 \mathrm{MHz}\right): \delta 0.81(\mathrm{t}, J=6.9 \mathrm{~Hz}, 6 \mathrm{H}), 1.24(\mathrm{~m}, 12 \mathrm{H}), 1.84(\mathrm{~m}, 4 \mathrm{H}), 2.23(\mathrm{~m}$, 4H), $5.15(\mathrm{~m}, 1 \mathrm{H}), 7.41(\mathrm{~m}, 1 \mathrm{H}), 7.64(\mathrm{~s}, 1 \mathrm{H}), 7.71(\mathrm{~m}, 2 \mathrm{H}), 7.79(\mathrm{dd}, J=5.5,2.8 \mathrm{~Hz}, 2 \mathrm{H}), 7.96$ (dd, $J=5.5,3.2 \mathrm{~Hz}, 2 \mathrm{H}), 8.64(\mathrm{~m}, 8 \mathrm{H})$. FAB MS: calcd. 793.32, found $795(\mathrm{M}+1)$.

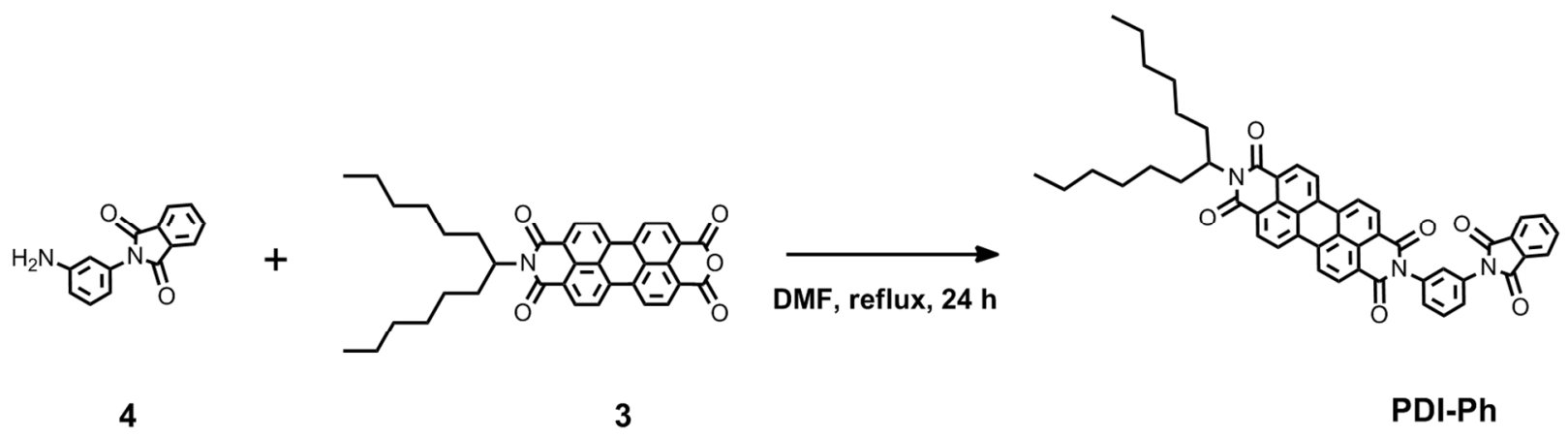

\section{Scheme S4}

\section{$N$-(3-Aminophenyl)-1,8-naphthalenedicarboximide (5)}

Naphthal anhydride (3.97 g, $20.03 \mathrm{mmol})$ and $m$-phenylenediamine (2.17 g, $20.07 \mathrm{mmol})$ were dissolved in $30 \mathrm{~mL}$ of DMF. The reaction mixture was heated with stirring at $110{ }^{\circ} \mathrm{C}$ for $24 \mathrm{~h}$ under argon atmosphere. Afterwards the reaction mixture was evaporated in vacuo and further purified by column chromatography (silica gel; dichloromethane/ethyl acetate $(1: 20, \mathrm{v} / \mathrm{v}))$ to obtain the yellow solid 5 (2.01 g, $6.97 \mathrm{mmol}, 35 \%)$. 
${ }^{1} \mathrm{H} \mathrm{NMR}\left(\mathrm{CDCl}_{3}, 400 \mathrm{MHz}\right): \delta 3.78(\mathrm{br}, 2 \mathrm{H}), 6.62(\mathrm{t}, J=2.1 \mathrm{~Hz}, 1 \mathrm{H}), 6.69(\mathrm{~d}, J=7.8 \mathrm{~Hz}$, 1H), $6.78(\mathrm{dd}, J=8.2,2.3 \mathrm{~Hz}, 1 \mathrm{H}), 7.31(\mathrm{t}, J=8.0 \mathrm{~Hz}, 1 \mathrm{H}), 7.77(\mathrm{t}, J=7.8 \mathrm{~Hz}, 2 \mathrm{H}), 8.26(\mathrm{~d}, J=$ $8.3 \mathrm{~Hz}, 2 \mathrm{H}), 8.64(\mathrm{t}, J=8.5 \mathrm{~Hz}, 2 \mathrm{H})$.

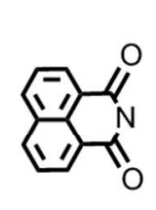

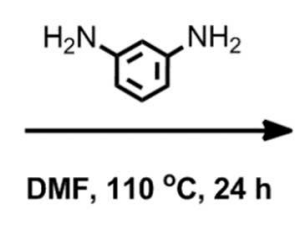

Scheme S5

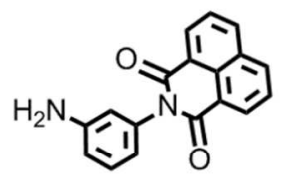

5

\section{PDI-NI}

$5(0.49 \mathrm{~g}, 1.70 \mathrm{mmol})$ and $3(0.65 \mathrm{~g}, 1.13 \mathrm{mmol})$ were dissolved in $40 \mathrm{~mL}$ of DMF. The reaction mixture was heated with stirring to reflux for $7 \mathrm{~d}$ under argon atmosphere. Afterwards the reaction mixture was evaporated in vacuo and purified by column chromatography (silica gel; dichloromethane). Further purification was carried by column chromatography (silica gel; dichloromethane/ethyl acetate (gradient)) to obtain the dark red solid PDI-NI (52 mg, $0.06 \mathrm{mmol}$, $5 \%$ ).

${ }^{1} \mathrm{H} \mathrm{NMR}\left(\mathrm{CDCl}_{3}, 400 \mathrm{MHz}\right): \delta 0.82(\mathrm{~m}, 6 \mathrm{H}), 1.23(\mathrm{~m}, 12 \mathrm{H}), 1.84(\mathrm{~m}, 4 \mathrm{H}), 2.23(\mathrm{~m}, 4 \mathrm{H}), 5.19$ (m, 1H), $7.42(\mathrm{~s}, 1 \mathrm{H}), 7.51(\mathrm{~m}, 1 \mathrm{H}), 7.75(\mathrm{~m}, 4 \mathrm{H}), 8.27(\mathrm{~d}, J=8.3 \mathrm{~Hz}, 2 \mathrm{H}), 8.65(\mathrm{~m}, 10 \mathrm{H})$. FAB MS: calcd. 843.33, found $845(\mathrm{M}+1)$. 


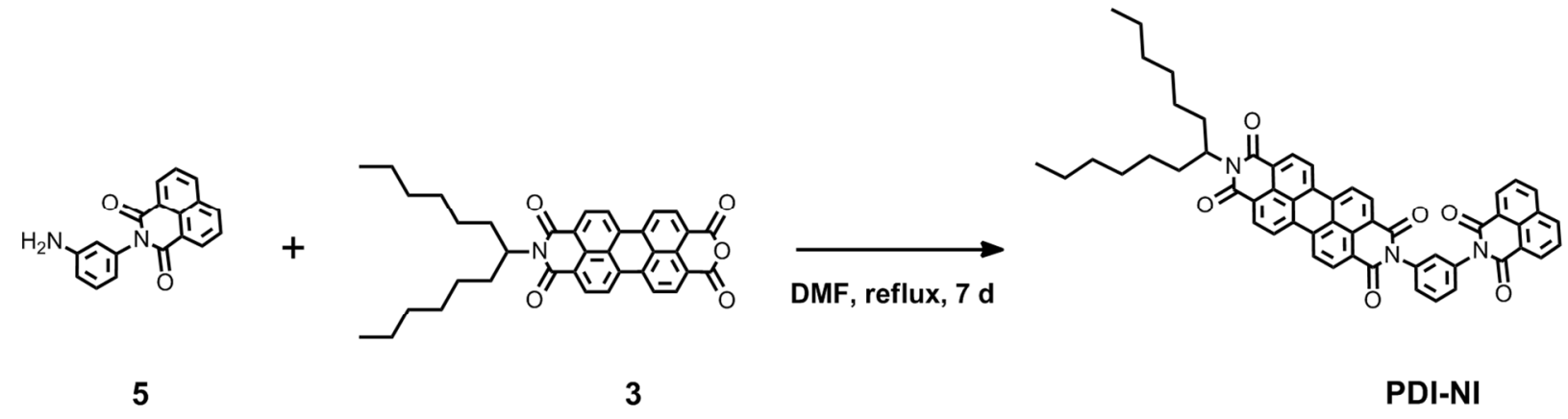

Scheme S6

\section{$N$-(2-Ethylhexyl)benzene-1,2-dicarboxyanhydride-4,5-dicarboximide (6)}

1,2,4,5-Benzenetetracarboxylic dianhydride $(8.95 \mathrm{~g}, 41.03 \mathrm{mmol})$ was placed in $100 \mathrm{~mL}$ of DMF and heated to $80{ }^{\circ} \mathrm{C}$. 2-Ethyl-1-hexylamine $(5.29 \mathrm{~g}, 40.93 \mathrm{mmol})$ dissolved in $30 \mathrm{~mL}$ of DMF was added drop wise to the reaction flask over a period of $3 \mathrm{~h}$. The reaction mixture was heated at $110^{\circ} \mathrm{C}$ under argon atmosphere. After $24 \mathrm{~h}$, the reaction mixture was cooled to room temperature. Disubstituted precipitate was removed by filtration. The DMF filtrate was then evaporated in vacuo and the tacky residue was dissolved in dichloromethane. Some unreacted starting material precipitated from dichloromethane as a white solid and was easily filtered off. The filtrate was evaporated in vacuo. Further purification was achieved by column chromatography (silica gel; dichloromethane/ethyl acetate (gradient)). After the column, the tacky material dissolved in acetic anhydride was heated at $80^{\circ} \mathrm{C}$ for $8 \mathrm{~h}$ to yield the pale yellow solid 6 (1.28 g, $3.89 \mathrm{mmol}, 10 \%)$.

${ }^{1} \mathrm{H}$ NMR $\left(\mathrm{CDCl}_{3}, 400 \mathrm{MHz}\right): \delta 0.87(\mathrm{~m}, 6 \mathrm{H}), 1.27(\mathrm{~m}, 8 \mathrm{H}), 1.84(\mathrm{~m}, 1 \mathrm{H}), 3.64(\mathrm{~d}, J=6.9 \mathrm{~Hz}$, $2 \mathrm{H}), 8.32(\mathrm{~s}, 2 \mathrm{H})$. 

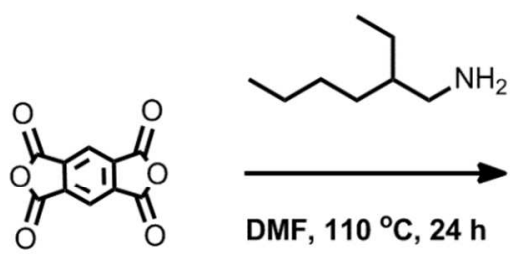

DMF, $110^{\circ} \mathrm{C}, 24 \mathrm{~h}$

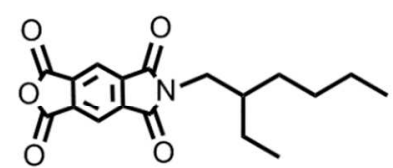

6

\section{Scheme S7}

\section{2-(3-Aminophenyl)-6-(2-ethylhexyl)pyrrolo[3,4-f] isoindole-1,3,5,7(2H,6H)-tetraone (7)}

$m$-Phenylenediamine $(0.29 \mathrm{~g}, 2.68 \mathrm{mmol})$ was dissolved in $50 \mathrm{~mL}$ of DMF and heated to 80 ${ }^{\circ} \mathrm{C}$. To this solution 6 ( $\left.0.88 \mathrm{~g}, 2.67 \mathrm{mmol}\right)$ dissolved in $50 \mathrm{~mL}$ of DMF was added drop wise over a period of $20 \mathrm{~h}$. The reaction mixture was heated at $110{ }^{\circ} \mathrm{C}$ for $24 \mathrm{~h}$ under argon atmosphere. The reaction mixture was concentrated under reduced pressure, and then dissolved in $50 \mathrm{~mL}$ of dichloromethane, and washed with water $(120 \mathrm{~mL} \times 3)$. Afterwards the solution was extracted by dichloromethane/ethyl acetate and evaporated in vacuo to give a crude product. Further purification was carried by column chromatography (silica gel; dichloromethane and then dichloromethane/ethyl acetate (gradient)) to obtain the yellow solid 7 (0.37 g, $0.88 \mathrm{mmol}, 33 \%)$.

${ }^{1} \mathrm{H}$ NMR (CDCl $\left.3,400 \mathrm{MHz}\right): \delta 0.87(\mathrm{~m}, 6 \mathrm{H}), 1.29(\mathrm{~m}, 8 \mathrm{H}), 1.86(\mathrm{~m}, 1 \mathrm{H}), 3.65(\mathrm{~d}, J=6.9 \mathrm{~Hz}$, 2H), 3.84 (br, 2H), $6.74(\mathrm{~m}, 2 \mathrm{H}), 6.81(\mathrm{~d}, J=6.9 \mathrm{~Hz}, 1 \mathrm{H}), 7.29$ (m, 1H), 8.37 (s, 2H).

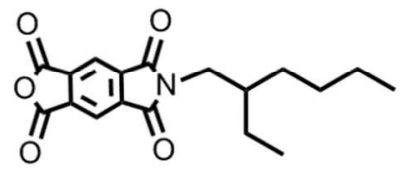

6

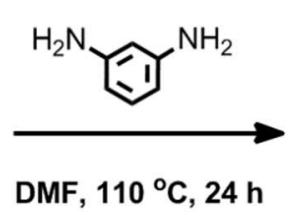

DMF, $110^{\circ} \mathrm{C}, 24 \mathrm{~h}$<smiles>CCCCC(CC)Cn1c(=O)c2cc3c(=O)n(-c4cccc(N)c4)c(=O)c3cc2c1=O</smiles>

7

Scheme S8 


\section{PDI-PI}

$7(0.37 \mathrm{~g}, 0.88 \mathrm{mmol})$ and $3(0.51 \mathrm{~g}, 0.89 \mathrm{mmol})$ were dissolved in $30 \mathrm{~mL}$ of DMF. The reaction mixture was heated with stirring to reflux for $10 \mathrm{~d}$ under argon atmosphere. Afterwards the reaction mixture was evaporated in vacuo and purified by column chromatography (silica gel; chloroform and then chloroform/ethyl acetate (gradient)). Further purification was carried by column chromatography (silica gel; dichloromethane and then dichloromethane/ethyl acetate (gradient)) to obtain the dark red solid PDI-PI (50 mg, $0.05 \mathrm{mmol}, 6 \%$ ).

${ }^{1} \mathrm{H}$ NMR $\left(\mathrm{CDCl}_{3}, 400 \mathrm{MHz}\right): \delta 0.81(\mathrm{~m}, 12 \mathrm{H}), 1.24(\mathrm{~m}, 21 \mathrm{H}), 1.84(\mathrm{~m}, 4 \mathrm{H}), 2.20(\mathrm{~m}, 4 \mathrm{H})$, $3.65(\mathrm{~d}, J=7.3 \mathrm{~Hz}, 2 \mathrm{H}), 5.16(\mathrm{~m}, 1 \mathrm{H}), 7.43(\mathrm{~m}, 1 \mathrm{H}), 7.65(\mathrm{~m}, 1 \mathrm{H}), 7.72(\mathrm{~m}, 2 \mathrm{H}), 8.37(\mathrm{~s}, 2 \mathrm{H})$, $8.62(\mathrm{~m}, 8 \mathrm{H})$. FAB MS: calcd. 974.43, found $976(\mathrm{M}+1)$.

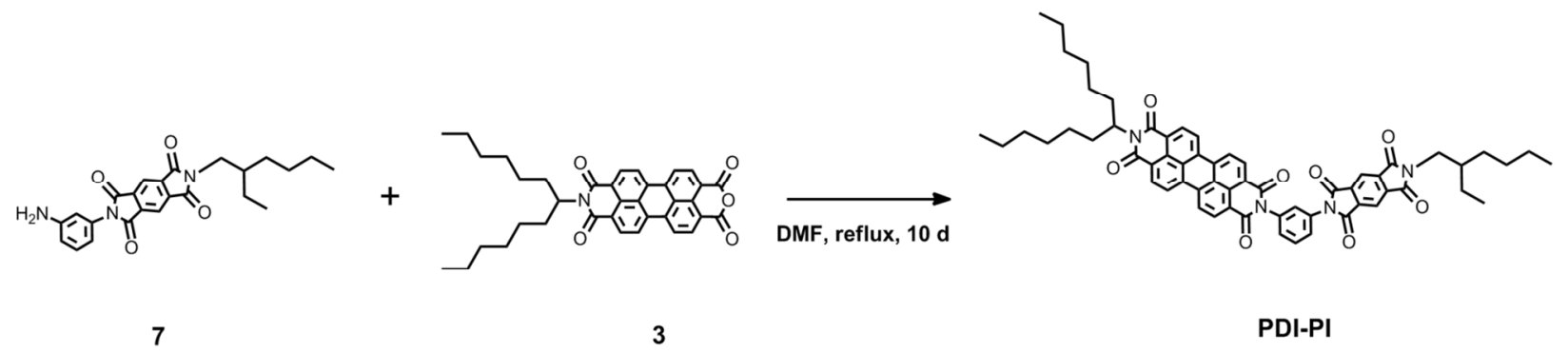

Scheme S9

\section{$N$-(2-Ethylhexyl)naphthalenetetracarboxylic monoanhydride monoimide (8)}

In a single-neck round-bottom flask equipped with a reflux condenser, 1,4,5,8-naphthalenetetracarboxylic dianhydride $(6.18 \mathrm{~g}, 23.04 \mathrm{mmol})$ was suspended in $80 \mathrm{~mL}$ of DMF, and the solution was stirred to $80{ }^{\circ} \mathrm{C}$. To this solution 2-ethyl-1-hexylamine (2.98 $\mathrm{g}$, $23.06 \mathrm{mmol}$ ) was added drop wise over a period of $1 \mathrm{~h}$ and the mixture was heated at $120{ }^{\circ} \mathrm{C}$ 
under argon atmosphere. After 24 hours, the reaction mixture was cooled to room temperature and the precipitated diimide were filtered off. DMF was evaporated under reduced pressure. The crude material was purified by column chromatography (silica gel; dichloromethane) to obtain the pale yellow solid 8 (4.09 g, $10.78 \mathrm{mmol}, 47 \%)$.

$\left.{ }^{1} \mathrm{H} \mathrm{NMR} \mathrm{(CDCl}, 400 \mathrm{MHz}\right): \delta 0.87(\mathrm{t}, J=6.9 \mathrm{~Hz}, 3 \mathrm{H}), 0.93(\mathrm{t}, J=7.3 \mathrm{~Hz}, 3 \mathrm{H}), 1.30(\mathrm{~m}, 8 \mathrm{H})$, $1.91(\mathrm{~m}, 1 \mathrm{H}), 4.10(\mathrm{~m}, 2 \mathrm{H}), 8.82(\mathrm{~m}, 4 \mathrm{H})$.
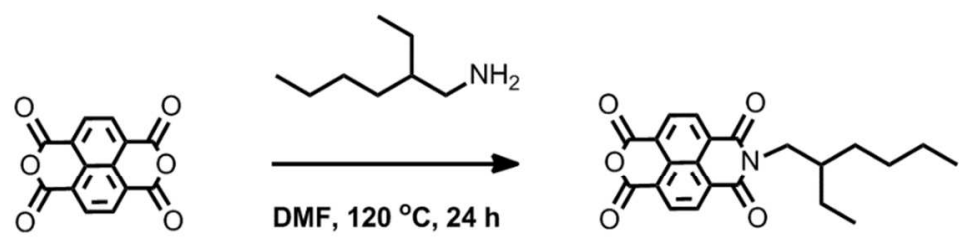

8

Scheme S10

\section{2-(3-Aminophenyl)-7-(2-ethylhexyl)benzo[ $[m n][3,8]$ phenanthroline-1,3,6,8(2H,7H)-tetrao} ne (9)

$8(0.97 \mathrm{~g}, 2.78 \mathrm{mmol})$ and $m$-phenylenediamine $(0.35 \mathrm{~g}, 3.24 \mathrm{mmol})$ were dissolved in $40 \mathrm{~mL}$ of DMF. The reaction mixture was heated with stirring at $120{ }^{\circ} \mathrm{C}$ for $24 \mathrm{~h}$ under argon atmosphere. Afterwards the reaction mixture was evaporated in vacuo, purified by column chromatography (silica gel; dichloromethane and then dichloromethane/ethyl acetate (gradient)) and concentrated to obtain the dark brown solid 9 (0.56 g, $1.19 \mathrm{mmol}, 43 \%)$.

${ }^{1} \mathrm{H}$ NMR $\left(\mathrm{CDCl}_{3}, 400 \mathrm{MHz}\right): \delta 0.87(\mathrm{t}, J=6.9 \mathrm{~Hz}, 3 \mathrm{H}), 0.93(\mathrm{t}, J=7.3 \mathrm{~Hz}, 3 \mathrm{H}), 1.31(\mathrm{~m}, 8 \mathrm{H})$, $1.93(\mathrm{~m}, 1 \mathrm{H}), 3.82(\mathrm{br}, 2 \mathrm{H}), 4.12(\mathrm{~m}, 2 \mathrm{H}), 6.61(\mathrm{t}, J=2.1 \mathrm{~Hz}, 1 \mathrm{H}), 6.68(\mathrm{~d}, J=7.8 \mathrm{~Hz}, 1 \mathrm{H}), 6.80$ (dd, $J=8.2,2.3 \mathrm{~Hz}, 1 \mathrm{H}), 7.32(\mathrm{t}, J=8.0 \mathrm{~Hz}, 1 \mathrm{H}), 8.80(\mathrm{~m}, 4 \mathrm{H})$. 


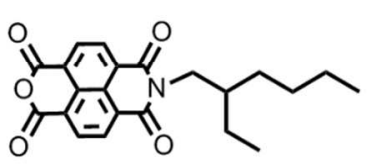

8

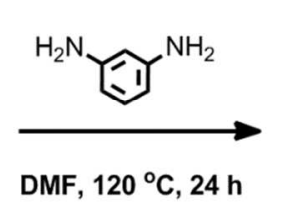

DMF, $120^{\circ} \mathrm{C}, 24 \mathrm{~h}$

9

\section{Scheme S11}

\section{PDI-NDI}

$9(0.11 \mathrm{~g}, 0.23 \mathrm{mmol})$ and $3(0.11 \mathrm{~g}, 0.19 \mathrm{mmol})$ were dissolved in $40 \mathrm{~mL}$ of DMF. The reaction mixture was heated with stirring to reflux for $4 \mathrm{~d}$ under argon atmosphere. Afterwards the reaction mixture was evaporated in vacuo and purified by column chromatography (silica gel; chloroform and then chloroform/ethyl acetate (gradient)). Further purification was carried by column chromatography (silica gel; dichloromethane and then dichloromethane/ethyl acetate (gradient)) to obtain the dark red solid PDI-NDI (50 mg, $0.05 \mathrm{mmol}, 26 \%$ ).

${ }^{1} \mathrm{H}$ NMR $\left(\mathrm{CDCl}_{3}, 400 \mathrm{MHz}\right): \delta 0.82(\mathrm{~m}, 12 \mathrm{H}), 1.23(\mathrm{~m}, 16 \mathrm{H}), 1.86(\mathrm{~m}, 6 \mathrm{H}), 2.18(\mathrm{~m}, 6 \mathrm{H})$, $4.02(\mathrm{~m}, 3 \mathrm{H}), 5.15(\mathrm{~m}, 1 \mathrm{H}), 7.41(\mathrm{~s}, 1 \mathrm{H}), 7.51(\mathrm{~m}, 2 \mathrm{H}), 7.76(\mathrm{t}, J=7.6 \mathrm{~Hz}, 1 \mathrm{H}), 8.44(\mathrm{~m}, 12 \mathrm{H})$. FAB MS: calcd. 1025.44, found $1027(\mathrm{M}+1)$.

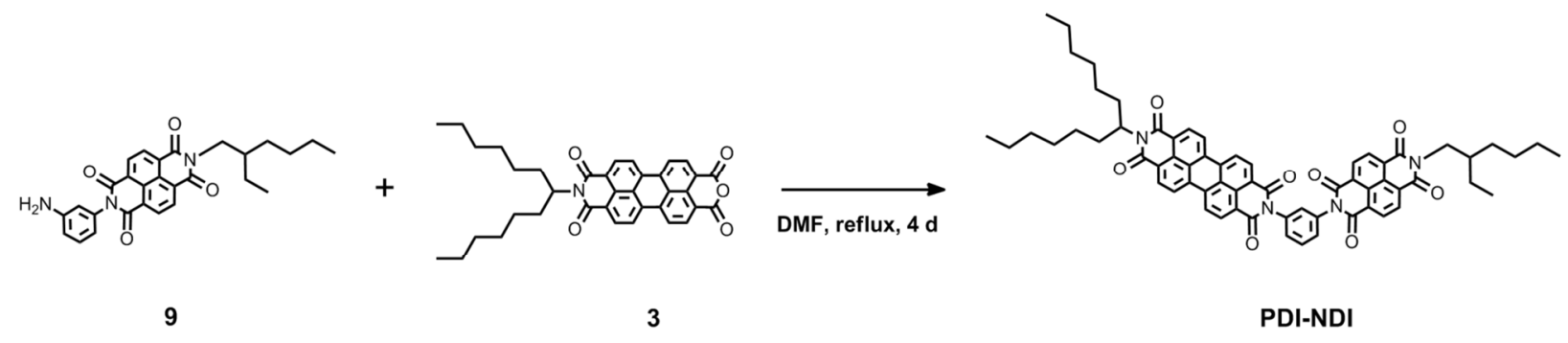

Scheme S12 


\section{PDI-PDI}

$3(0.92 \mathrm{~g}, 1.60 \mathrm{mmol})$ and $m$-phenylenediamine $(0.09 \mathrm{~g}, 0.83 \mathrm{mmol})$ were dissolved in $40 \mathrm{~mL}$ of DMF. The reaction mixture was heated with stirring to reflux for $4 \mathrm{~d}$ under argon atmosphere. Afterwards the reaction mixture was evaporated in vacuo and purified by column chromatography (silica gel; chloroform and then chloroform/ethyl acetate (gradient)). Further purification was carried by column chromatography (silica gel; dichloromethane and then dichloromethane/ethyl acetate (gradient)) to obtain the dark red solid PDI-PDI (50 mg, 0.04 $\mathrm{mmol}, 5 \%)$.

${ }^{1} \mathrm{H} \mathrm{NMR}\left(\mathrm{CDCl}_{3}, 400 \mathrm{MHz}\right): \delta 0.81(\mathrm{t}, J=6.9 \mathrm{~Hz}, 12 \mathrm{H}), 1.23(\mathrm{~m}, 32 \mathrm{H}), 1.83(\mathrm{~m}, 4 \mathrm{H}), 2.22$ (m, 4H), $5.14(\mathrm{~m}, 2 \mathrm{H}), 7.46(\mathrm{~s}, 1 \mathrm{H}), 7.54(\mathrm{~d}, J=7.8 \mathrm{~Hz}, 2 \mathrm{H}), 7.77(\mathrm{t}, J=8.0 \mathrm{~Hz}, 1 \mathrm{H}), 8.64(\mathrm{~m}$, 16H). FAB MS: calcd. 1218.55, found $1220(\mathrm{M}+1)$.

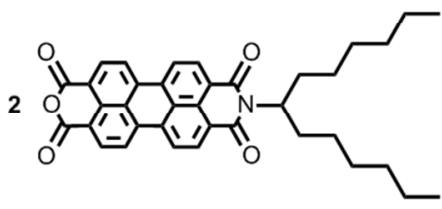

3

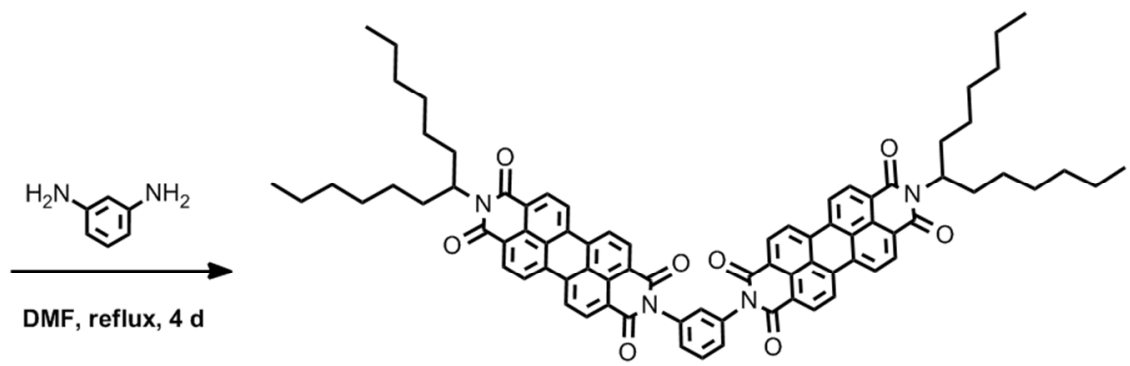

PDI-PDI

Scheme S13 
Kinetic traces

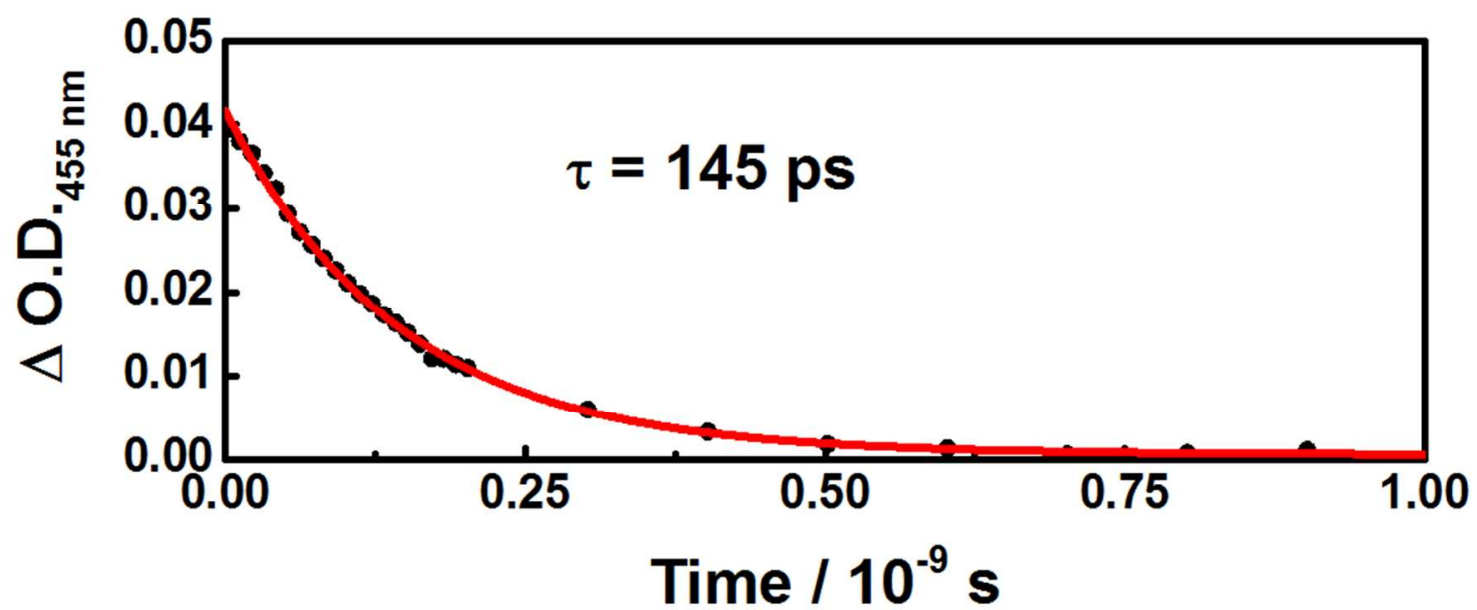

Figure S1. Kinetic trace of $\Delta$ O.D. at $455 \mathrm{~nm}$ during the $700 \mathrm{~nm}$ laser flash photolysis of PDI (60 $\mu \mathrm{M})$ in DMF in the presence of TDAE $(60 \mu \mathrm{M})$.

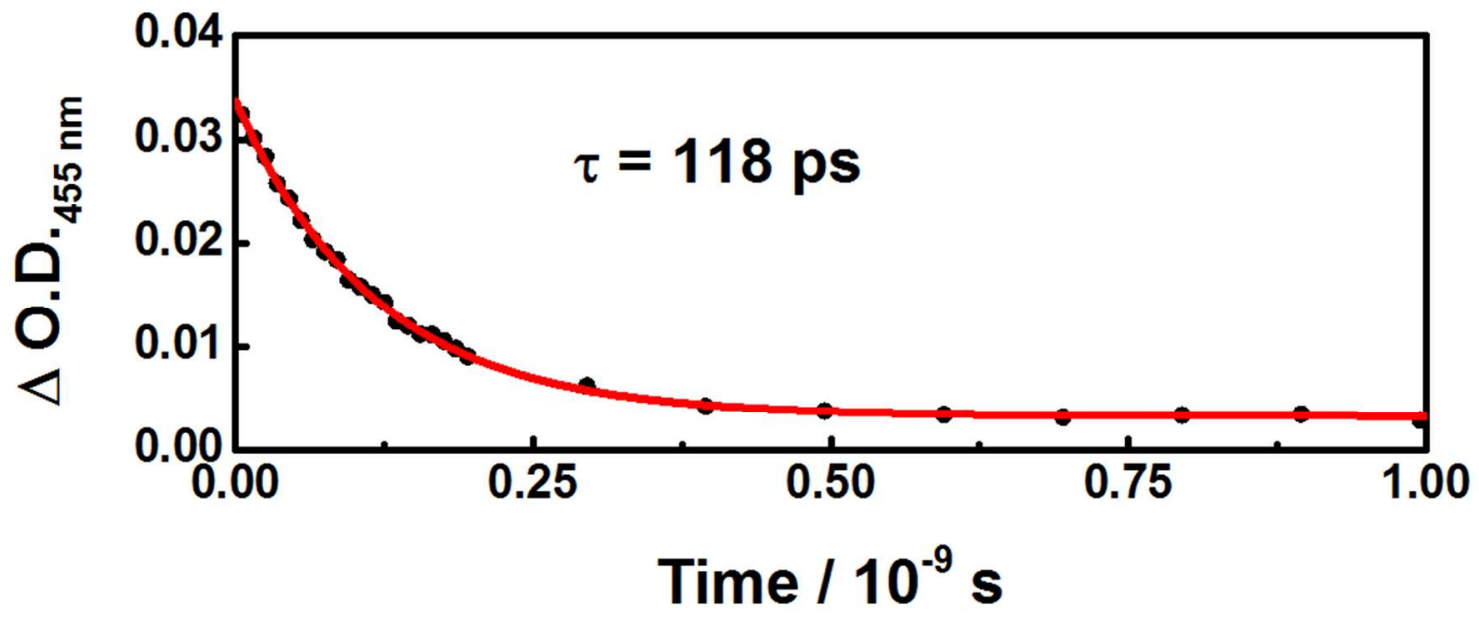

Figure S2. Kinetic trace of $\Delta$ O.D. at $455 \mathrm{~nm}$ during the $700 \mathrm{~nm}$ laser flash photolysis of PDI-PI $(60 \mu \mathrm{M})$ in DMF in the presence of TDAE $(60 \mu \mathrm{M})$. 

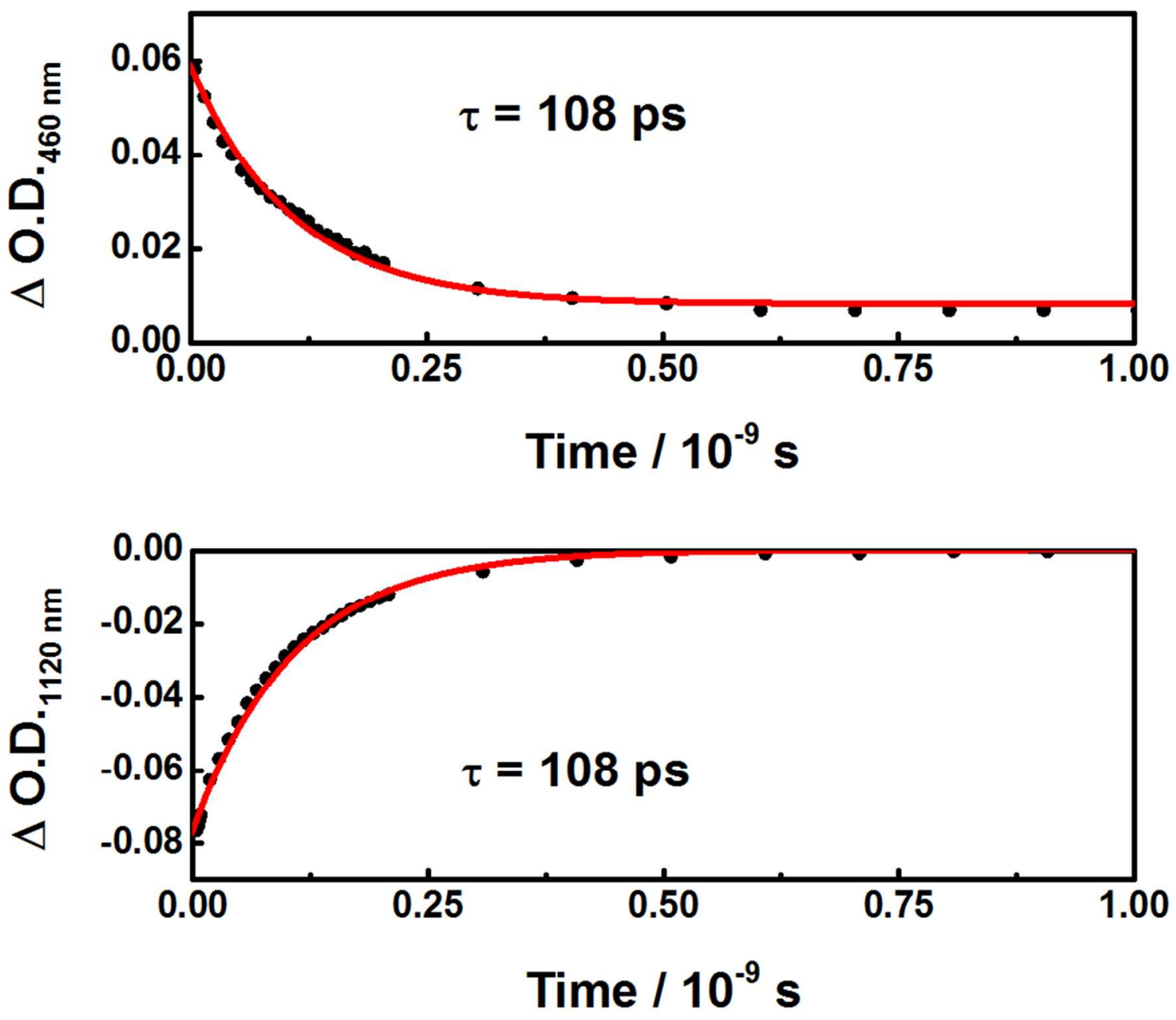

Figure S3. Kinetic traces of $\Delta$ O.D. at $460 \mathrm{~nm}$ (top panel) and $1120 \mathrm{~nm}$ (bottom panel) during the $700 \mathrm{~nm}$ laser flash photolysis of PDI-PDI $(0.12 \mathrm{mM})$ in DMF in the presence of TDAE $(0.24$ $\mathrm{mM})$.

\section{Complete author list of ref. 45}

(45) Frisch, M. J.; Trucks, G. W.; Schlegel, H. B.; Scuseria, G. E.; Robb, M. A.; Cheeseman, J. R.; Scalmani, G.; Barone, V.; Mennucci, B.; Petersson, G. A.; Nakatsuji, H.; Caricato, M.; Li, X.; Hratchian, H. P.; Izmaylov, A. F.; Bloino, J.; Zheng, G.; Sonnenberg, J. L.; Hada, M.; Ehara, M.; Toyota, K.; Fukuda, R.; Hasegawa, J.; Ishida, M.; Nakajima, T.; Honda, Y.; Kitao, O.; 
Nakai, H.; Vreven, T.; Montgomery, J. A., Jr.; Peralta, J. E.; Ogliaro, F.; Bearpark, M.; Heyd, J. J.; Brothers, E.; Kudin, K. N.; Staroverov, V. N.; Kobayashi, R.; Normand, J.; Raghavachari, K.; Rendell, A.; Burant, J. C.; Iyengar, S. S.; Tomasi, J.; Cossi, M.; Rega, N.; Millam, N. J.; Klene, M.; Knox, J. E.; Cross, J. B.; Bakken, V.; Adamo, C.; Jaramillo, J.; Gomperts, R.; Stratmann, R. E.; Yazyev, O.; Austin, A. J.; Cammi, R.; Pomelli, C.; Ochterski, J. W.; Martin, R. L.; Morokuma, K.; Zakrzewski, V. G.; Voth, G. A.; Salvador, P.; Dannenberg, J. J.; Dapprich, S.; Daniels, A. D.; Farkas, Ö.; Foresman, J. B.; Ortiz, J. V.; Cioslowski, J.; Fox, D. J. Gaussian 09, Revision C. 01. Guassian, Inc.: Wallingford, CT 2009. 